\title{
New records of host-parasite relationships between Coenagrion scitulum (Rambur, 1842) (Odonata) and water mite larvae (Hydrachnidia) in core and edge host populations
}

\author{
Andrzej Zawal ${ }^{1 *}$, Lieven Therry2,3, Robby Stoks ${ }^{2}$ and Grzegorz Michoński ${ }^{1}$ \\ ${ }^{1}$ Department of Invertebrate Zoology and Limnology, The Centre for Molecular Biology and Biotechnology, University of Szczecin, \\ Waska 13, 71 - 415 Szczecin, Poland; ${ }^{2}$ Laboratory of Aquatic Ecology, Evolution and Conservation, KU Leuven, Deberiotstraat 32 , \\ B-3000 Leuven, Belgium ; ${ }^{3}$ Station d'Ecologie Théorique et Expérimentale UMR5321, CNRS, 2 Route du CNRS, F-09200 Moulis, France
}

\begin{abstract}
The relationships between water mite larvae parasitizing Coenagrion scitulum in core and edge populations were described. A total of 636 larvae of 7 water mite species were found on 143 C. scitulum adults ( 82 females and 61 males). C. scitulum was recorded for the first time as a host species for Arrenurus cuspidator, A. bruzelii, A. bicuspidator, A. tricuspidator, A. claviger and Hydryphantes octoporus. The degree of infestation by particular parasite species was typical for these species. In contrast, the parasites' preferences for host body parts were not typical, as they preferred abdominal segments $2-4$, which in earlier studies had been avoided by water mite larvae. No differences were found in degree of infestation of Coenagrion scitulum individuals between core and edge populations, with the exception of Hydryphantes octoporus, which parasitized damselflies only in core populations.
\end{abstract}

\section{Keywords}

Arrenurus, Hydryphantes octoporus, damselfly, ectoparasitism, infestation

\section{Introduction}

Water mites (Hydrachnidia) belong to the Parasitengona because their larvae parasitize aquatic insects. This strategy allows water mites to disperse and colonize new water bodies (Bilton et al. 2001; Zawal 2003a, 2003b; Bohonak et al. 2004; Martin 2008). There are two means of infestation: one group of mites parasitizes insects permanently abiding in water and leaving this environment only periodically, i.e. beetles and true bugs (Cichocka 1995; Zawal 2002, 2003c; Fairn et al. 2008; Incekara and Erman 2008; Zawal et al. 2013; Abe et al. 2015), and the other group parasitizes insects whose larvae live in the water, while the adults permanently abide outside of the water (Davids 2004; Zawal 2004a, 2004b, 2006a, 2006b; Buczyńska et al. 2015; Stryjecki et al. 2015). The larvae of Arrenurus, parasitizing damselflies, belong to the latter group (Zawal, 2004a; 2004b, 2006a, 2006b; Baker et al. 2006, 2007, 2008; Zawal and Jaskuła 2008; Radhakrishnan et al. 2010; Kulijer et al. 2012; Kulijer et al. 2013; Kaunisto et al. 2015; Młynarek et al. 2015).
Two mechanisms may cause differentiation in the degree of parasitism between core and edge populations of the host species. Firstly, metapopulation theory predicts that infestation of the host population by parasites is enhanced by close proximity to patches with extant host populations (Boyett et al. 2000; Hanski 1999). Kaunisto et al. (2015) showed that the number of water mite larvae infesting Coenagrion hastulatum decreases from core to edge populations in Finland. Secondly, stressful conditions at range edges have been linked to poorer body condition (Pitt et al. 2008; Busch et al. 2011) and this may impair investment in immune function making individuals more susceptible to parasites at the range margins (Briers 2003). In contrast, in the specific case of moving range margins, a higher investment in immune function at the leading range edge has been documented (Therry et al. 2014a) which has the potential to decrease parasite susceptibility at edge populations. Theoretical (e.g., Travis and Dytham 2002) and empirical studies (reviewed in Hill et al. 2011) indicated the evolution of increased dispersal abilities during range expansion. 
Dispersers are often larger (Anholt 1990; Michiels and Dhondt 1991) or in better body condition than residents (Sundström 1995). Given that immune function is often positively correlated with individual condition (Yang et al. 2007), one may also expect a higher immune function at the leading range edge. Furthermore, selection for a high investment in immune function to lower parasite load may be enhanced through the negative effect of high parasite load on dispersal ability (e.g. Nagel et al. 2010).

There is no information available about the host-parasite relationships in core and edge populations of range expanding damselflies. Therefore, the key objective of this paper was to investigate differences in water mite infestation between core and edge populations of the poleward moving damselfly C. scitulum (Swaegers et al. 2013). In addition, we investigate new water mite associations with $C$. scitulum to extend the knowledge on water mite parasitism in this host species.

\section{Materials and Methods}

One hundred and forty-three adults of C. scitulum ( 82 females and 61 males) were captured in 2010 and 2011 in small water bodies in France ( $\mathrm{C} 1$ - Le Bouchet $46^{\circ} 43^{\prime} 13.99^{\prime \prime} \mathrm{N}$ $1^{\circ} 10^{\prime} 20.19^{\prime \prime} \mathrm{E}, \mathrm{C} 2$ - Vauville $49^{\circ} 37^{\prime} 10.11^{\prime \prime} \mathrm{N} 1^{\circ} 50^{\prime} 24.21^{\prime \prime} \mathrm{W}$, $\mathrm{C} 3$ - Roussent $50^{\circ} 21^{\prime} 50.35^{\prime \prime} \mathrm{N} 1^{\circ} 47^{\prime \prime} 09.58^{\prime \prime} \mathrm{E}, \mathrm{C} 4$ - Merlimont $50^{\circ} 26^{\prime} 17.26^{\prime \prime} \mathrm{N} 1^{\circ} 35^{\prime} 17.67^{\prime \prime} \mathrm{E}$ ), Germany (E1 - Abweiler $49^{\circ} 12^{\prime} 54.48^{\prime \prime} \mathrm{N} 7^{\circ} 11^{\prime} 38.37^{\prime \prime} \mathrm{E}, \mathrm{E} 2$ - Webenheim 4914' $52.96^{\prime \prime} \mathrm{N}$ $7^{\circ} 16^{\prime} 18.91^{\prime \prime} \mathrm{E}, \mathrm{E} 3$ - Zülpich 50 $\left.41^{\prime} 54.25^{\prime \prime} \mathrm{N} 6^{\circ} 38^{\prime} 59.33^{\prime \prime} \mathrm{E}\right)$, Belgium (E4 - De Panne 51 ${ }^{\circ} 06^{\prime} 06.16^{\prime \prime} \mathrm{N} 2^{\circ} 36^{\prime} 31.64^{\prime \prime} \mathrm{E}$, E5 Knokke $51^{\circ} 21^{\prime} 30.81^{\prime \prime} \mathrm{N} 3^{\circ} 20^{\prime} 33.02^{\prime \prime} \mathrm{E}$ ) and The Netherlands (E6 - Cadzand $51^{\circ} 22^{\prime} 50.19^{\prime \prime} \mathrm{N} 3^{\circ} 23^{\prime} 58.61^{\prime \prime} \mathrm{E}$ ) (Fig. 1). Up to the $1990 \mathrm{~s}$ the northern range limit of C. scitulum was situated in Northern France, where after a north-eastward range expansion occurred (Swaegers et al. 2013). The populations of C. scitulum in France were located within the historical distribution of the species and were defined as core populations (Swaegers et al. 2013). The populations in Germany, Belgium and The Netherlands were situated at the expansion front and founded less than five years before sampling and were defined as edge populations (Therry et al. 2014b).

Water mite larvae were removed with tweezers. The body length of the larvae was measured from the frontal part of the gnathosoma to the end of the idiosoma. The larvae were identified using a key by Zawal (2008).

Intensity of infestation (number parasites per individual of host) relative to hosts, sexes of hosts, parts of host body and hosts from particular populations were analysed.

Statistical significance between intensity of infestation was determined by the Kruskal-Wallis and Mann-Whitney tests in Statistica v. 12.5 software. The effect of population status (core vs edge) was analysed on log-transformed mite scores using mixed models (SAS v. 9.3) with replicated populations status as random effect.

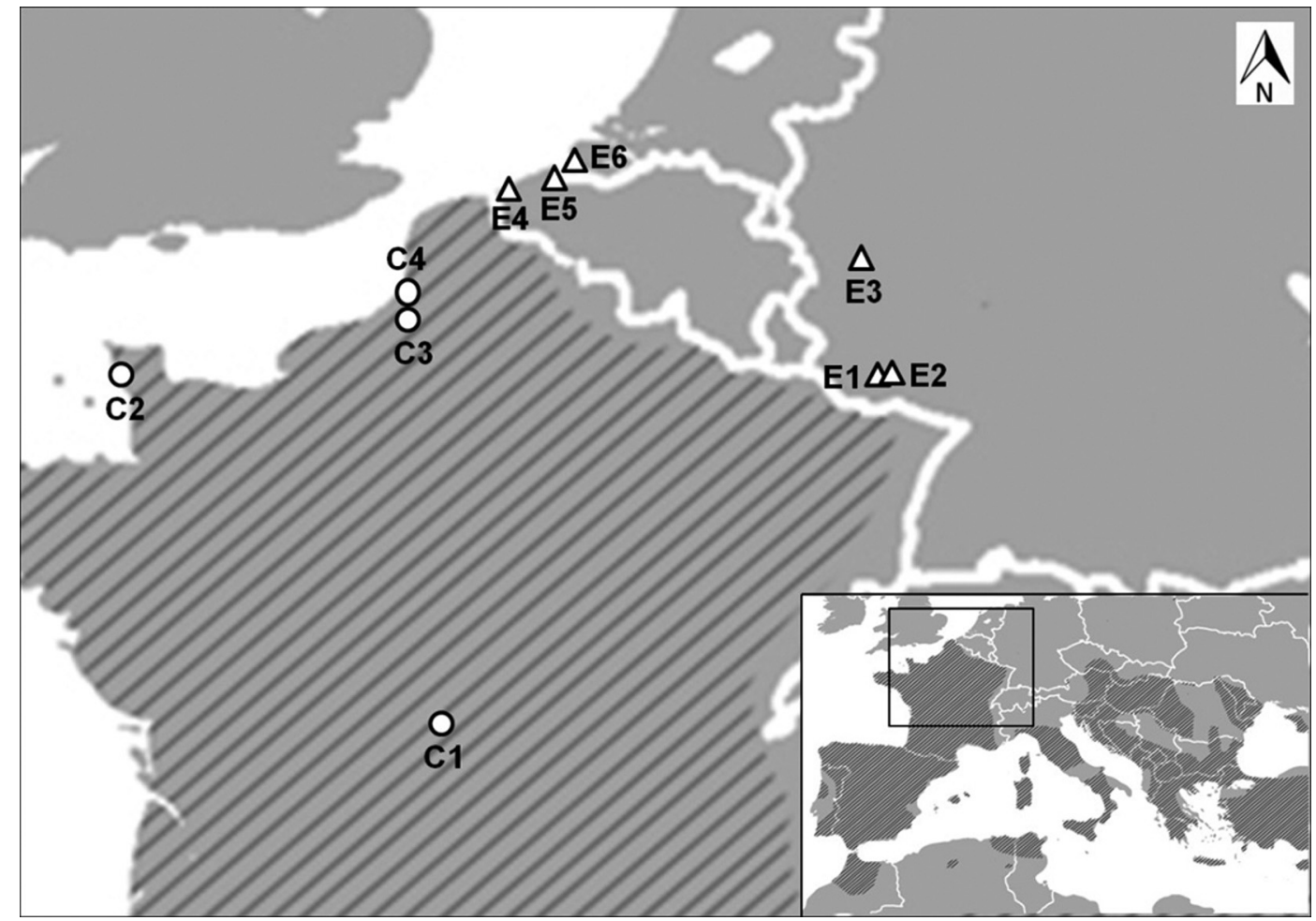

Fig. 1. Locations of the C. scitulum study populations and the European historical species' range (shaded area based on Dijkstra 2006). Core populations are indicated with circles and edge populations are indicated by triangles 
Table I. Overview table of the water mite species on the damselfly C. scitulum with characteristics of the infestation patterns. nh - number of host individuals, $\mathrm{np}$ - number of parasite individuals

\begin{tabular}{|c|c|c|c|c|c|c|c|c|c|c|c|c|}
\hline \multirow{2}{*}{ Parasite species } & \multicolumn{8}{|c|}{ Females } & \multicolumn{4}{|c|}{ males } \\
\hline & $\mathrm{nh}$ & $\mathrm{np}$ & range & $\begin{array}{c}\text { average } \pm \\
\text { STD }\end{array}$ & $\mathrm{nh}$ & $\mathrm{np}$ & range & $\begin{array}{c}\text { average } \pm \\
\text { STD }\end{array}$ & $\mathrm{nh}$ & np & range & $\begin{array}{c}\text { average } \pm \\
\text { STDd }\end{array}$ \\
\hline A. bicuspidator & 12 & 24 & $1-8$ & $1.9 \pm 1.98$ & 5 & 15 & $1-8$ & $3.0 \pm 2.53$ & 7 & 9 & 1 & 1.0 \\
\hline A. bruzelii & 45 & 208 & $1-22$ & $4.6 \pm 4.30$ & 42 & 202 & $1-22$ & $4.8 \pm 4.23$ & 3 & 6 & $1-2$ & $1.3 \pm 0.58$ \\
\hline A. claviger & 1 & 2 & $2-28$ & $15.0 \pm 13.00$ & 1 & 2 & 2 & 2.0 & & & & \\
\hline A. cuspidator & 76 & 344 & $1-30$ & $4.5 \pm 5.08$ & 32 & 110 & $1-15$ & $3.3 \pm 2.96$ & 44 & 234 & $1-30$ & $5.4 \pm 6.02$ \\
\hline A. maculator & 1 & 25 & 25 & 25.0 & 1 & 25 & 25 & 25.0 & & & & \\
\hline A. tricuspidator & 1 & 4 & 4 & 4.0 & 1 & 4 & 4 & 4.0 & & & & \\
\hline H. octoporus & 7 & 29 & $1-11$ & $3.9 \pm 3.66$ & & & & & 7 & 29 & $1-11$ & $4.1 \pm 3.83$ \\
\hline TOTAL & 143 & 636 & $1-30$ & $4.6 \pm 5.22$ & 82 & 358 & $1-25$ & $4.3 \pm 4.35$ & 61 & 278 & $1-30$ & $4.6 \pm 5.52$ \\
\hline
\end{tabular}

\section{Results}

A total of 636 water mite larvae were recorded on the sampled $C$. scitulum individuals. These belonged to six species of water mites from the subgenus Arrenurus s. str. and one from the genus Hydryphantes (Table I). The Kruskal-Wallis test revealed no significant differences between the degree of infestation of all water mite species $(\mathrm{H}(6, \mathrm{~N}=147)=11.88, \mathrm{p}=$ $0.065)$, but showed statistically significant differences between degree of infestation for the most numerous species (A. bicuspidator (Berl.), A. bruzelii (Koen.), A. cuspidator (Müll.), A. maculator (Müll.) and Hydryphantes octoporus
(Koen.); $(\mathrm{H}(3, \mathrm{~N}=143)=7.945869 \mathrm{p}=0.0471)$. The intensity of infestation of all species tested did not differ between males (4.4 mean with 4.46 SE) and females (4.1 mean with $5.60 \mathrm{SE}$ ) (Kruskal-Wallis test, $\mathrm{N}=19, \mathrm{H} 1=2.15, \mathrm{p}=0.14$ ), but statistically significant differences between the intensity of infestation of host sexes for A. bruzelii and A. cuspidator (Mann-Whitney $\mathrm{U}$ test: $\mathrm{Z}=-1.3657 \mathrm{p}=0.0172$ and $\mathrm{Z}=-$ $1.1679 \mathrm{p}=0.0243)$. Arrenurus bruzelii infested females much more often and in greater numbers, while $A$. cuspidator infested males and females with equal frequency, but the intensity of infestation of males was markedly higher (Table I). The intensity of infestation (Fig. 2) did not differ between

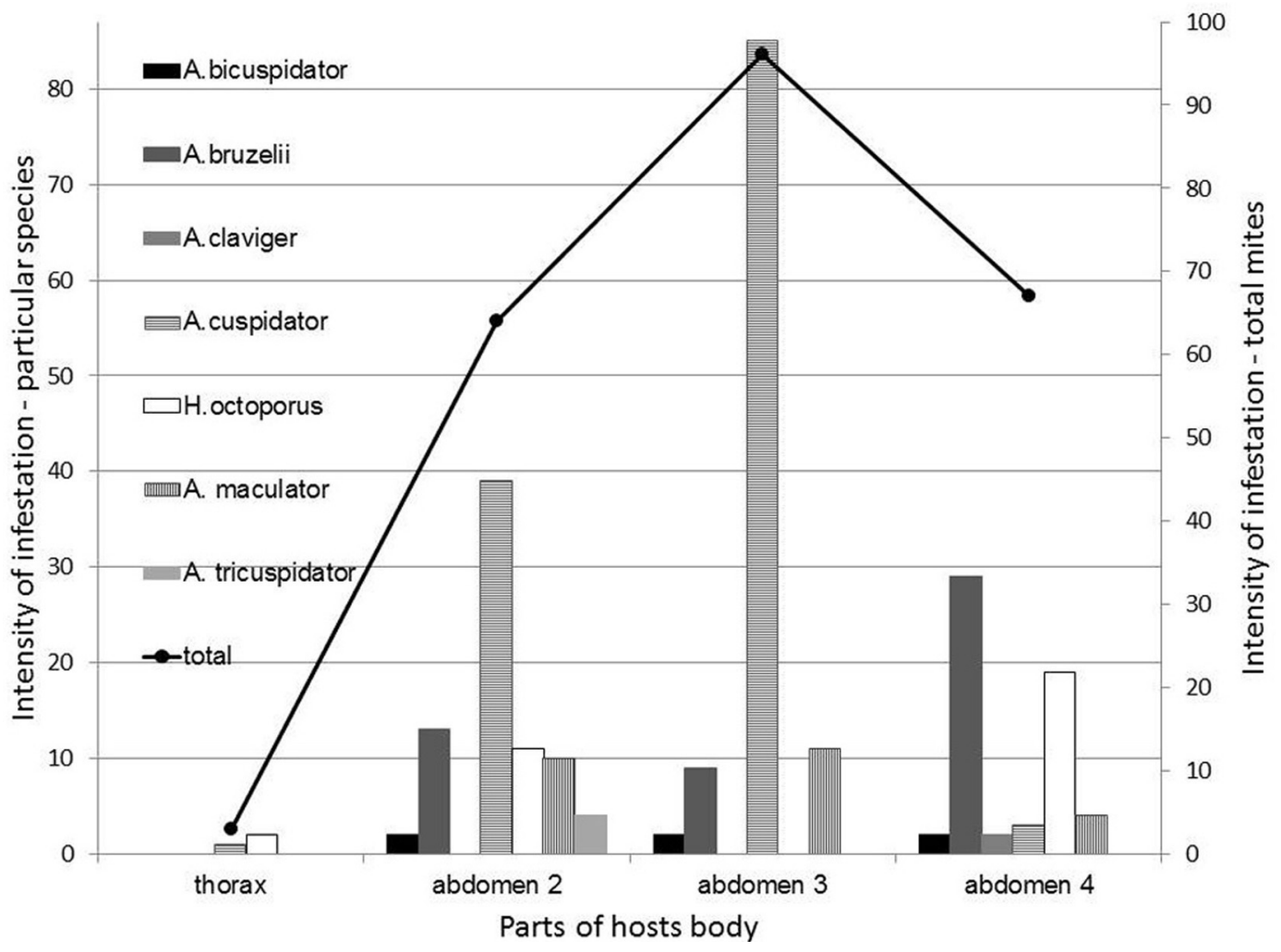

Fig. 2. The occurrence of water mites on the different body parts of the damselfly host C. scitulum 


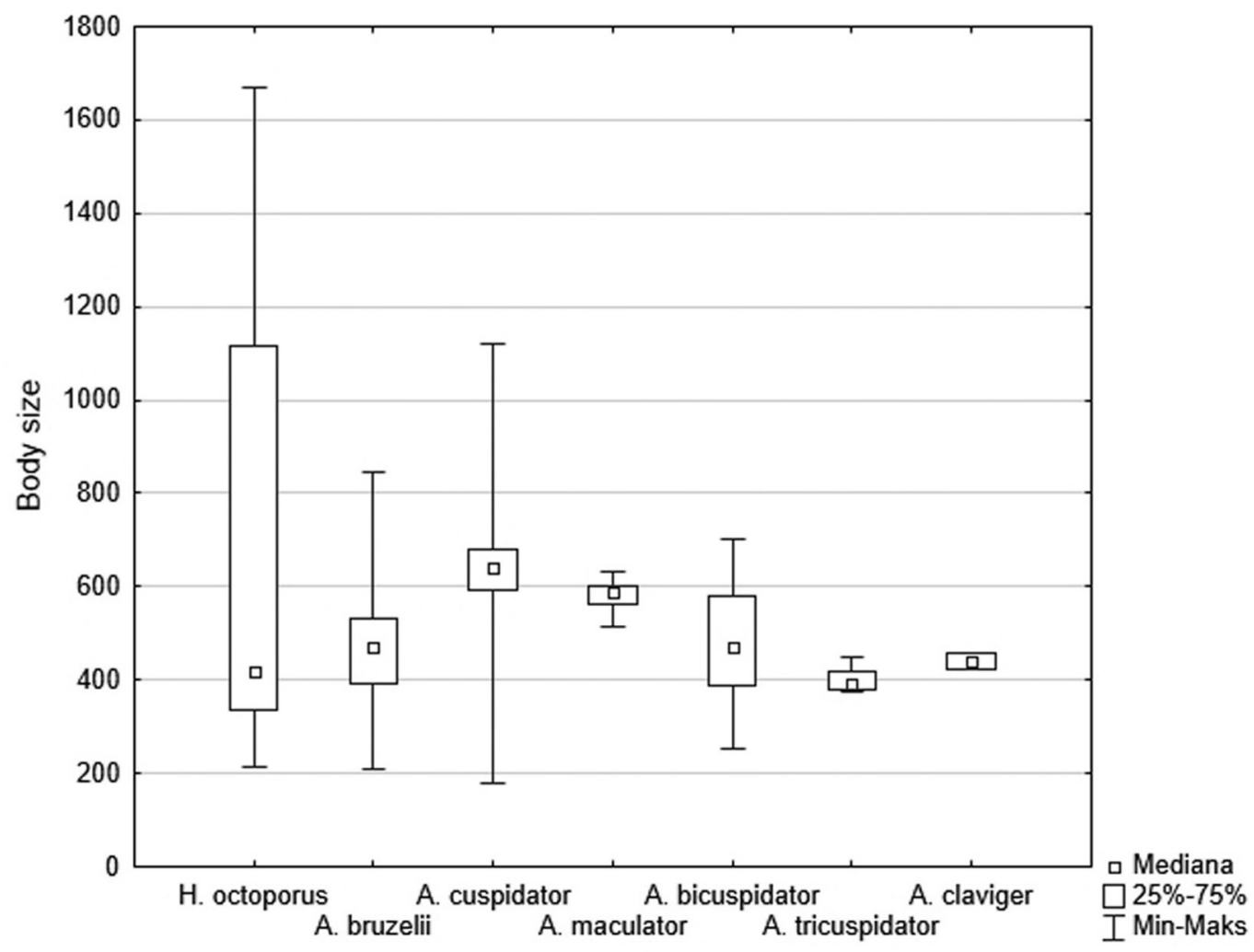

Fig. 3. Body size of water mite larvae

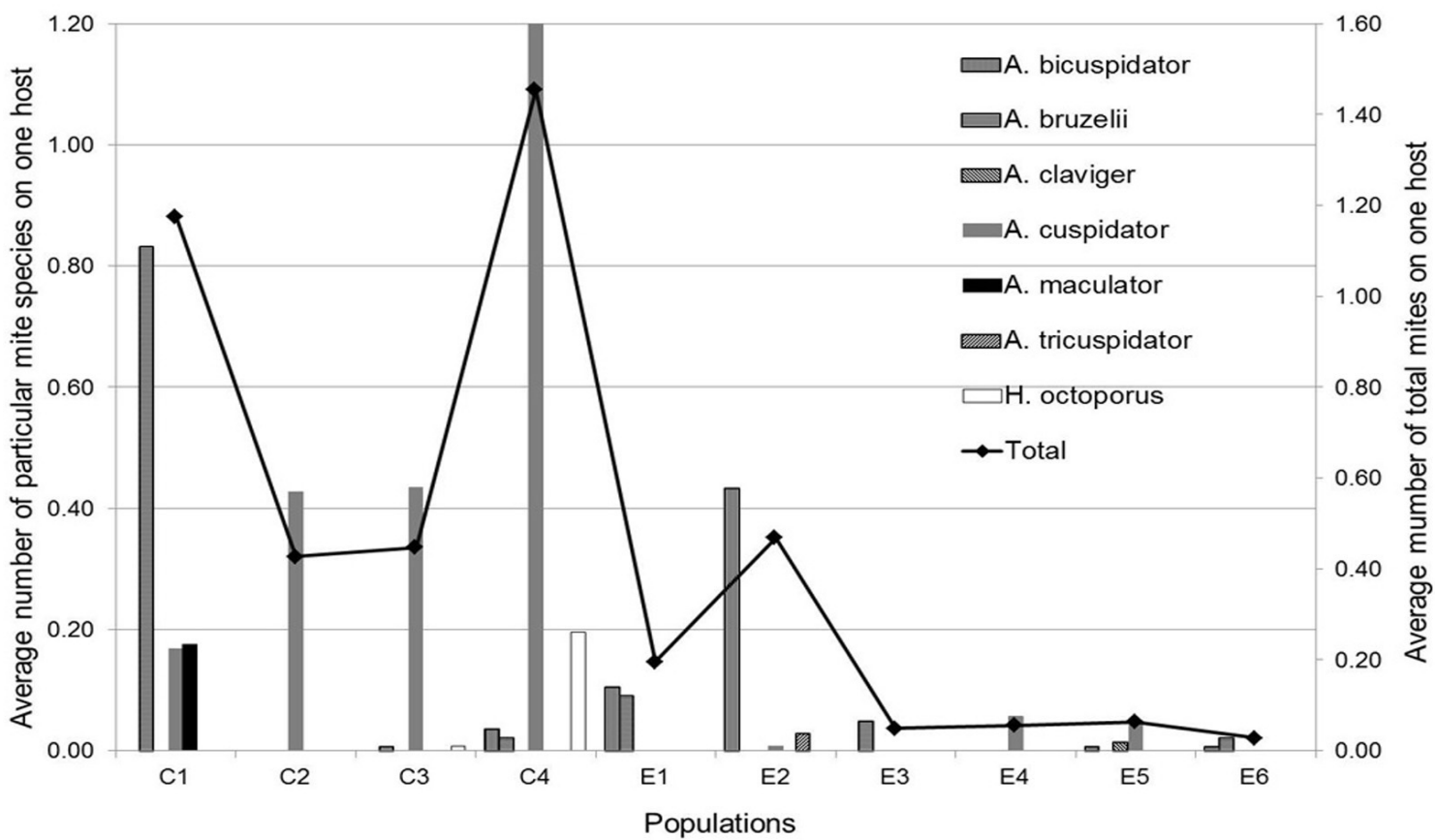

Fig. 4. Average number of parasites on one host in particular hosts' populations 


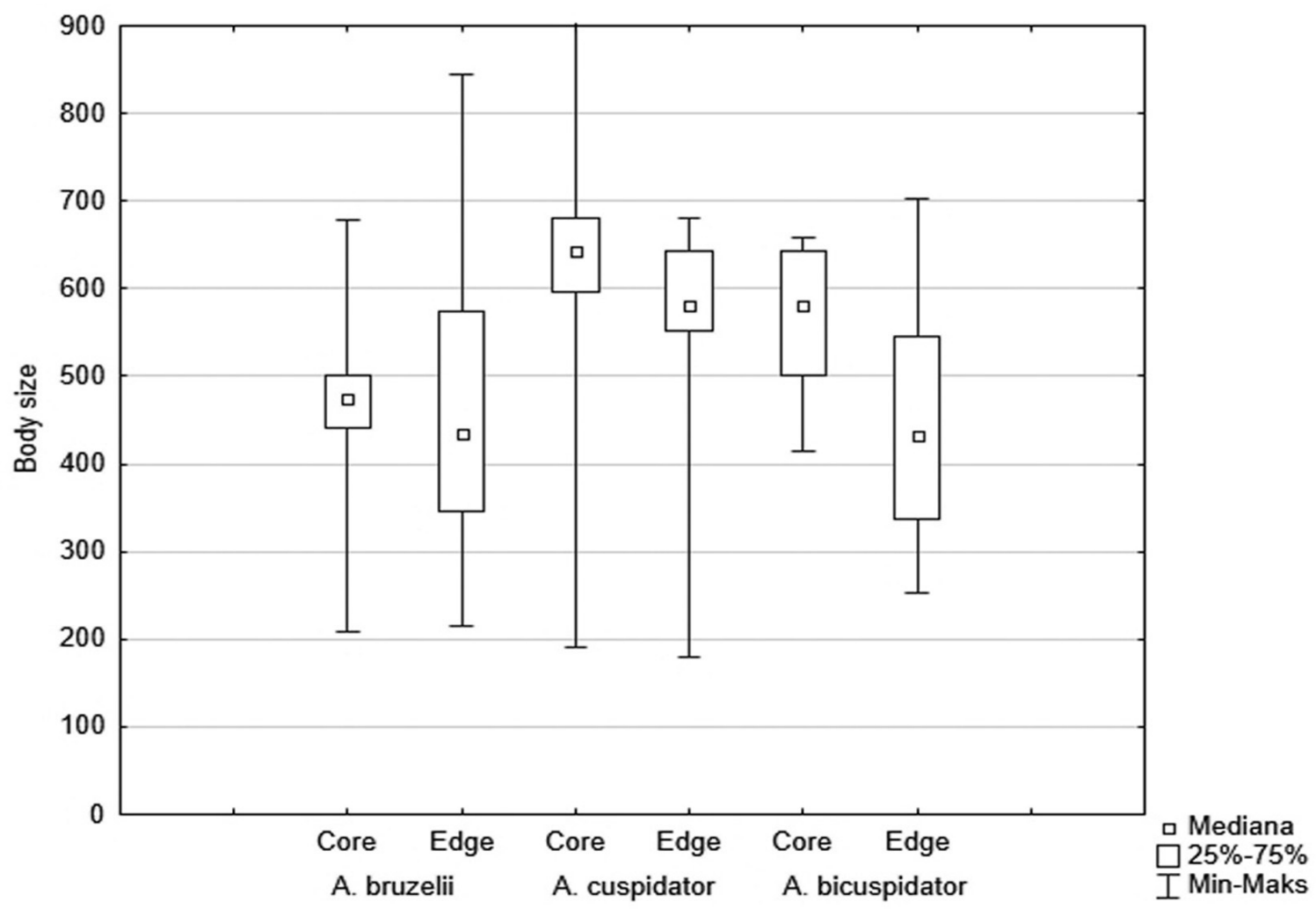

Fig. 5. Body size of parasites in core and edge hosts' populations

body parts of the hosts (Kruskal-Wallis test: $\mathrm{H}(3, \mathrm{~N}=42)=$ 2.66, $\mathrm{p}=0.4462$ ).

The body size of water mite larvae varied from 180 to $1668 \mu \mathrm{m}$. The widest range of values was noted for $H$. octoporus. This species was also distinguished by the largest larvae, but $A$. cuspidator had the largest mean body size (Fig. 3). The differences are statistically significant (Kruskal-Wallis test: $\mathrm{H}(6, \mathrm{~N}=520)=181.50, \mathrm{p}<0.001)$.

total of seven water mite species were observed, with the number of species per population ranging from one to four (Fig. 4). Two species, A. tricuspidator (Müll.) and A. claviger (Koen.), were each found in only one edge population and one species, A. maculator was only found in one core population. Another species, $H$. octoporus, was found in only two core populations (Fig. 4). Core (4.6 mean with 5.45 SE) and edge (3.3 mean with 2.19 SE) populations did not differ in the number of attached water mites per adult damselfly $\left(\mathrm{F}_{1,6.72}=0.54\right.$, $\mathrm{p}=0.488$ ), but high variation was noted among populations with the same population status (core vs edge) (random effect population nested in population status: Wald $\mathrm{Z}=26.1$, $\mathrm{df}=1$, $\mathrm{p}<0.001)$.

Statistically significant differences were observed between the body size of water mite larvae in core and edge populations both for all species of parasites together (Kruskal-Wallis test: $\mathrm{H}(6, \mathrm{~N}=520)=181.50, \mathrm{p}<0.001)$ and for the most numerous species (A. cuspidator) (Fig. 5) (Mann-Whitney $\mathrm{U}$ test $\mathrm{Z}=-2.38, \mathrm{p}=0.0175)$.

\section{Discussion}

C. scitulum is a damselfly species on which parasitizing larvae of only two water mite species (A. maculator and A. radiatus) had previously been recorded (Davids 1997). The present study adds another six species to this list of parasites (Table I). The species of the genus Arrenurus noted here are widely distributed opportunists in terms of host species, previously recorded on numerous odonate species (Zawal 2004a, 2006a, 2006b; Ilvonen et al. 2016). In contrast, H. octoporus is an exception in the family Hydryphantidae, parasitizing Odonata (Zawal and Dyatlova 2008; Kulijer et al. 2013) while the all other species of the family parasitize Heteroptera and Diptera (Smith and Olivier 1986).

The intensity of infestation of C. scitulum does not vary between individual parasite species and the intensity of infestation is similar as observed in other Odonata species (Zawal 2004a, 2006a, 2006b).

A general rule in Coenagrionidae is that adult males spend more time near a water body while the adult females disperse in the vicinity and return to the water to breed (Dijkstra 2006). This also applies to C. scitulum, with the females characterized by substantially greater dispersion (Angelibert and Giani 2003). Ilvonen et al. (2016) found no differences in infestation by water mites between the two sexes of damselflies, which conflicts with the data presented by Rob and Forbes (2005), who observed a higher infestation by water mites for females 
of Lestes disjunctus. The case described in the present study is interesting, with different strategies adopted by two parasite species, A. bruzelii and A. cuspidator. A. bruzelii is a species associated with small water bodies, occurring frequently but generally not abundantly (Gerecke et al. 2016), which in the light of the results obtained here may result from its parasitism strategy involving a preference for female damselflies. A. cuspidator, on the other hand, is a very common and abundant species, which may be linked to the frequent infestation of both sexes of damselflies as well as the higher infestation rate of males. This is confirmed by earlier data for other host species of the family Coenagrionidae (Baker et al. 2008; Zawal and Buczyński 2013).

The number of attached parasites did not differ between body parts which is not typical for damselflies, as previous literature (Zawal 2004a, 2006a, 2006b). Abdominal segments 1-3 are passed over by water mite larvae, probably due to their connection with reproduction (Baker et al. 2007).

The body size of the parasites noted here was markedly different from that of newly hatched larvae (Zawal 2006c, 2006d, 2006e; Tuzovskij 2007), indicating that they had been parasitizing the hosts for a long time, which is consistent with the sampling time. Previous studies indicate spring and early summer as the period when most Arrenurus larvae hatch (Daszkiewicz and Zawal 2004; Włodarczyk and Zawal 2004; Dzierzgowska et al. 2011; Kłosowska et al. 2011; Bańkowska et al. 2016).

The theory of metapopulations suggests a decrease in the abundance of species towards the boundaries of their range, and to a large extent this applies to parasites as well (Price 1980). Kaunisto et al. (2015) demonstrated a pronounced reduction in water mite larva of the genus Arrenurus parasitizing Coenagrion hastulatum in Finland. In this case it was linked to the climatic zone, which caused the abundance of both hosts and parasites to decrease as latitude increased. The present study did not confirm previous results, as the ranges of parasite (water mite) species were considerably wider than the host range (C. scitulum). In consequence the edge host populations were attacked by core populations of parasites. Interestingly, C. scitulum individuals from edge populations have a higher immune function than core individuals when reared at common garden conditions (Therry et al. 2014a), yet this did not translate into higher immune function in the wild (Therry et al. 2014b) nor into lower mite parasitism in edge populations. H. octoporus was noted only in core populations, which is in line with previous studies whereby the species has been recorded as a parasite of odonates exclusively in the south of Europe (Zawal and Dyatlova 2008; Kulijer et al. 2013). H. octoporus as a adult was found in almost whole Europe (Di Sabatino et al. 2010), but up to now nothing is known about its parasitizing in North Europe. The differences noted between core and edge populations in the body size of the parasites are likely due to climate differences, as higher temperatures lead to faster development of parasites in the core populations located further south.

\section{References}

Abé H., Ohtsuka Y., Ohba S. 2015. Water mites (Acari: Hydrachnidiae) parasitic on aquatic hemipterans in Japan, with reference to host preferences and selection sites. International Journal of Acarology, 41, 494-506. DOI.10.1080/01647954. 2015.1073357

Angelibert S., Giani N. 2003. Dispersal characteristics of three odonate species in a patchy habitat. Ecography, 26, 13-20. DOI: $10.1034 /$ j.1600-0587.2003.03372.x

Anholt B.R. 1990. Size-biased dispersal prior to breeding in a damselfly. Oecologia, 83, 385-387. DOI: 10.1007/BF00317564

Baker R.A., Mill P.J., Zawal A. (Eds) 2006. Mites on aquatic insects - studies in biodiversity and exploitation. In: (Eds. V. Pešić and S. Hadžiablahović) II International Symposium of Ecologists of Montenegro - Proceedings of the Symposium, 1-9

Baker R.A., Mill P.J., Zawal A. 2007. Mites on Zygoptera, with particular reference to Arrenurus species, selection sites and host preferences. Odonatologica, 36, 339-347

Baker R.A., Mill P.J., Zawal A. 2008. Ectoparasitic water mite larvae of the genus Arrenurus on the damselfly Coenagrion puella (Linnaeus) (Zygoptera: Coenagrionidae). Odonatologica, 31, 193-202

Bańkowska A., Kłosowska M., Gadawski P., Michoński G., Grabowski M., Pešić V., Pakulnicka J., Zawal A. 2016. Oviposition by selected water mite (Hydrachnidia) species from Lake Skadar and its catchment. Biologia, 71, 1027-1033. DOI: 10.1515/biolog-2016-0126

Bilton D. T., Freeland J.R., Okamura B. 2001. Dispersal in freshwater invertebrates. Annual Review of Ecology, Evolution, and Systematics, 32, 159-81

Bohonak A.J., Smith B.P., Thornton M. 2004, Distributional, morphological and genetic consequences of dispersal for temporary pond water mites. Freshwater Biology, 49, 170-180. DOI: $10.1111 / \mathrm{j} .1365-2426.2003 .01177 . x$

Boyett W.D., Endries M.J., Adler G.H. 2000. Colonization- extinction dynamics of opossums on small islands in Panama. $\mathrm{Ca}$ nadian Journal of Zoology-Revue Canadienne De Zoologie, 78, 1972-1979. DOI: 10.1139/z00-150

Briers R.A. 2003. Range limits and parasite prevalence in a freshwater snail. In: Proceedings of the Royal Society B-Biological Sciences, 270, 178-180. DOI: 10.1098/rsbl.2003.0046

Buczyńska E., Buczyński P., Zawal A., Michoński G., Szlauer-Łukaszewska A. 2015. First record of parasitism of water mite larva (Acari: Hydrachnidia) on the pupa of Trichoptera. Acta Parasitologica, 60, 196-199. DOI: 10.1080/01650424.2014.971816

Busch D.S., Robinson W.D., Robinson T.R., Wingfield J.C. 2011. Influence of proximity to a geographical range limit on the physiology of a tropical bird. Journal of Animal Ecology, 80, 640-649. DOI: 10.1111/j.1365-2656.2010.01791.x

Cichocka M. 1995. Parasitism by Hydracarina upon aquatic Heteroptera from the group Nepomorpha in the lakes of Szczytno. Acta Parasitologica, 40, 94-99

Daszkiewicz M., Zawal A. 2004. Płodność kilku gatunków wodopójek z podrodzajów Megaluracarus i Micruracarus w kontekście przystosowania do zmieniających się warunków środowiska. In: (Ed. M. Ciaciura) Stan środowiska przyrodniczego podstawowym warunkiem zdrowotności społeczeństwa, Optimex, Szczecin, 429-434

Davids C. 1997. Watermijten als parasieten van libellen. Brachytron, 1, 51-55. (In Dutch)

Davids C. 2004. Parasitisme bij watermijten. Entomologische Berichten, 64, 51-58. (In Dutch)

Di Sabatino A., Gerecke R., Gledhill T., Smit H. 2010. Chelicerata: Acari II. In: (Ed. R. Gerecke) Süßwasserfauna von Mitteleuropa, Vol. 7/2-2. Elsevier. München. 1-234. (In German) 
Dijkstra K.D.B. (Ed.) 2006. Field guide to the dragonflies of Britain and Europe. British Wildlife Publishing, Gillingham, $1-320$

Dzierzgowska K., Zawal A., Stojanovski S. 2011. Składanie jaj przez niektóre gatunki wodopójek (Hydrachnidia) z terenu Macedonii. In: (Eds D. Wysocki, J. Kaliciuk and P. Sadanowicz) Ogólnopolska Konferencja "Zwierzęta w życiu człowieka" oraz XX Jubileuszowy Zjazd Polskiego Towarzystwa Zoolo+gicznego, P.P.H. ZAPOL Dmochowski, Sobczyk, Szczecin, 42-48. (In Polish)

Fairn E.R., Schulte-Hostedde A.I., Alar1e Y. 2008. Water mite parasitism is associated with body condition and sex of the whirligig beetle Dineutus nigrior (Coleoptera: Gyrinidae) Ecoscience, 15, 327-331. DOI: 10.2980/15-3-3134Gerecke R., Gledhill T., Pešić, V., Smit H. 2016. Chelicerata: Acari III. In: (Ed. R. Gerecke), Süßwasserfauna von Mitteleuropa, Springer-Verlag Berlin, Heidelberg, 7/2-3, 1-429

Hanski I. (Ed.) 1999. Metapopulation Ecology. Oxford University Press, Oxford, 1-328

Hill J.K., Griffiths H.M. Thomas C.D. 2011. Climate change and evolutionary adaptations at species' range margins. Annual Review of Entomology, 56,143-159. DOI: 10.1146/annurev-ento120709-144746

Ilvonen J.J., Kaunisto K.M. Suhonen J. 2016. Are sexes equally parasitized in damselflies and dragonflies? Oikos 125, 315-325. DOI: $10.1111 /$ oik.02437

İncekara Ü., Erman O. 2008. The aquatic Coleoptera (Helophoridae and Hydrophilidae) species contributing the parasitism and phoresy, with main habitat characteristics in Erzurum and surroundings (East Anatolia). Turkiye Entomoloji Dergisi-Turkish Journal of Entomology, 32, 83-89

Kaunisto K.M., Kaunisto P., Vahtera V., Suhonen J. 2015. Populations of the damselfly Coenagrion hastulatum at the edge of the species range have fewer gregarine and water mite parasites. Freshwater Biology, 60, 794-801. DOI:10.1111/fwb.12534

Kłosowska M., Bańkowska A., Zawal A. 2011. Składanie jaj przez niektóre gatunki wodopójek (Hydrachnidia) z rzeki Krąpieli i jej zbiorników dolinnych. In: (Eds D. Wysocki, J. Kaliciuk and P. Sadanowicz) Ogólnopolska Konferencja "Zwierzęta w życiu człowieka" oraz XX Jubileuszowy Zjazd Polskiego Towarzystwa Zoologicznego, P.P.H. ZAPOL Dmochowski, Sobczyk, Szczecin, 60-65. (In Polish)

Kulijer D., Baker R.A., Zawal A. 2012. A preliminary report on parasitism of Odonata by water mites from Bosnia and Herzegovina. Journal of the British Dragonfly Society, 28, 92-101

Kulijer D., Zawal A., Baker R.A. 2013. Further studies on the Odonata from Bosnia and Herzegovina and their mite parasites. Journal of the British Dragonfly Society, 29, 97-99.

Martin P. 2008. Wassermilben (Hydrachnidia, Acari) und Insekten: Ein Überblick über eine selten betrachtete Beziehung. Entomologie heute, 20, 45-75

Michiels N.K., Dhondt A.A. 1991. Characteristics of dispersal in sexually mature dragonflies. Ecological Entomology, 16, 449459. DOI: 10.1111/j.1365-2311.1991.tb00238.x

Mlynarek J.J., Knee W., Mark R., Forbes M.R. 2015. Host phenology, geographic range size and regional occurrence explain interspecific variation in damselfly-water mite associations. Ecography, 38, 670-680. DOI: 10.1111/ecog.00997

Nagel I., Zanuttig M., Forbes M.R. 2010. Selection on mite engorgement size affects mite spacing, host damselfly flight, and host resistance. Evolutionary Ecology Research, 12, 653-665

Pitt J.A., Lariviere S., Messier F. 2008, Survival and body condition of racoons at the edge of the range. Journal of Wildlife Management, 72, 389-395. DOI: 10.2193/2005-761

Price P.W. (Ed.) 1980. Evolutionary Biology of Parasites. Oxford University Press, Guilford, Surrey, UK
Radhakrishnan V., Zawal A., Ramarajuk K. 2010. First record of parasitized Trithemis pallidinervis (Kirby) from Tamil Nadu, India by Arrenurus larvae, with a description of larval morphology (Anisoptera: Libellulidae; Acari: Hydrachnidia). Odonatologica, 39, 243-252

Robb T., Forbes M.R. 2005. On understanding seasonal increases in damselfly defence and resistance against ectoparasitic mites. Ecological Entomology, 30, 334-341. DOI: 10.1111/j.03076946.2005.00689.x

Smith I.M., Olivier D.R. 1986. Review of parasitic associations of larval water mites (Acari: Parasitengona: Hydrachnidia) with Insect hosts. The Canadian Entomologist, 118, 407-472. DOI.org/10.4039/Ent118407-5

Stryjecki R., Czepiel-Mil K., Gryzinska M., Zawal A. 2015. A very rare case of intersexuality in water mites of the genus Arrenurus Dugès, 1834 (Acari, Hydrachnidia). Invertebrate Reproduction and Development, 59, 155-165. DOI: 10.1080/ 07924259.2015 .1050560

Sundström L. 1995. Dispersal polymorphism and physiological condition of males and females in the ant, Formica truncorum. Behavioral Ecology, 6, 132-139. DOI: 10.1093/beheco/6.2.132

Swaegers J., Mergeay J, Therry L., Larmuseau M.H., Bonte D., Stoks R. 2013. Rapid range expansion increases genetic differentiation while causing limited reduction in genetic diversity in a damselfly. Heredity, 11, 422-429

Therry L., Nilsson-Örtman V., Bonte D., Stoks R. 2014a. Rapid evolution of larval life history, adult immune function and flight muscles in a poleward-moving damselfly. Journal of Evolutionary Biology, 27, 141-152. DOI.: 10.1111/jeb.12281

Therry L., Zawal A., Bonte D., Stoks R. 2014b. What factors shape female phenotypes of a poleward-moving damselfly at the edge of its range? Biological Journal of the Linnean Society, 112, 556-568. DOI: $10.1111 / \mathrm{bij} .12295$

Travis J.M.J., Dytham C. 2002. Dispersal evolution during invasions. Evolutionary Ecology Research, 4, 1119-1129

Tuzovskij P.V. 2007. Larval morphology of the water mite Hydryphantes octoporus Koenike (Acariformes: Hydryphantidae). Zoosystematica Rossica, 16, 19-22

Włodarczyk A., Zawal A. 2004. Porównanie płodności kilku gatunków wodopójek z podrodzaju Arrenurus s. str. ze środowisk o różnej antropopresji. In: (Ed. M. Ciaciura) Stan środowiska przyrodniczego podstawowym warunkiem zdrowotności spoteczeństwa, Optimex, Szczecin, 361-368. (In Polish)

Yang S., Ruuhola T., Rantala M.J. 2007. Impact of starvation on immune defense and other life-history traits of an outbreaking geometrid, Epirrita autumnata: a possible causal trigger for the crash phase of population cycle. Annales Zoologici Fennici, 44, 89-96

Zawal A. 2002. Parasitism of water mite (Hydrachnellae) larvae of genus Hydrachna on water beetles in Poland. Acarologia, 42, 361-370

Zawal A. 2003a. The role of insects in the dispersion of water mites Acta Biologica Universitatis Daugavpiliensis, 3, 9-14

Zawal A. 2003b. Strategia rozwoju a sukces reprodukcyjny niektórych wodopójek (Hydrachnellae). In: (Eds S. Rogalska and J. Domagała) Człowiek i środowisko przyrodnicze Pomorza Zachodniego. I Środowisko biotyczne, Uniwersytet Szczeciński Press, Szczecin, 135-137. (In Polish)

Zawal A. 2003c. Parasitism of water mite (Hydrachnellae) larvae of genus Eylais on water beetles in Poland. Acarologia, 43, 39-47

Zawal A. 2004a. Parasitizing of dragonflies by water mite larvae of the genus Arrenurus in the neighbourhood of Barlinek (NW Poland). Zoologica Poloniae, 49, 37-45

Zawal A. 2004b. Relacje pomiędzy larwami wodopójek z rodzaju Arrenurus a larwami ważek - foreza czy pasożytnictwo. Acta Biologica, 11, 153-162. (In Polish) 
Zawal A. 2006a. Relationships between dragonflies and water mite larvae (Hydrachnellae) of the genus Arrenurus. In: (Ed. S. Ignatowicz) Advances in Polish Acarology, SGGW, Warszawa. 469-476

Zawal A. 2006b. Phoresy and parasitis: water mite larvae of the genus Arrenurus (Acari: Hydrachnidia) on Odonata from Lake Binowskie (NW Poland). Biological Letters, 43, 257276

Zawal A. 2006c. Morphology of the larval stages of the water mites Arrenurus bicuspidator, A. tricuspidator, and A. tetracyphus (Arrenuridae). Acarina, 14, 89-96

Zawal A. 2006d. Morphology of larval stages of Arrenurus cuspidator (O. F. Müller) and A. maculator (O. F. Müller) (Acari: Hydrachnidia). Zootaxa, 1194, 57-68

Zawal A. 2006e. Larval morphology of Arrenurus cuspidifer Piersig, A. claviger Koenike, and A. latus Barrois and Moniez (Acari: Hydrachnidia). Zootaxa, 1276, 55-68

Zawal A. 2008. Morphological characteristics of water mite larvae of the genus Arrenurus Dugès, 1834, with notes on the phylogeny of the genus and an identification key. Zootaxa, 1765, $1-75$

Received: July 8, 2016

Revised: August 25, 2016

Accepted for publication: August 26, 2016
Zawal A., Buczyński P. 2013. Parasitism of Odonata by Arrenurus (Acari: Hydrachnidia) larvae in the Lake Świdwie, nature reserve (NW Poland). Acta Parasitologica, 58, 486-495. DOI: 10.2478/s11686-013-0162-6

Zawal A., Çamur-Elipek B., Fent M., Kırgız T., Dzierzgowska K. 2013. First observations in Turkish Thrace on water mite larvae parasitism of Ranatra linearis by Hydrachna gallica (Acari: Hydrachnidia). Acta Parasitologica, 58, 57-63. DOI: 10.2478/s11686-013-0106-1

Zawal A., Dyatlova E. 2008. Parasitizing on damselflies (Odonata: Coenagrionidae) by water mite (Acari: Hydrachnidia) larvae from Odessa province (Southwestern Ukraine). Natura Montenegrina, 7 453-462

Zawal A., Jaskuła R. 2008. First data for parasitising on Sympetrum meridionale (Sèlys) by Arrenurus (Acari: Hydrachnidia) larvae from Montenegro. Natura Montenegrina, 7: 354-359 